\title{
Risk Assessment of Bridge Fire Based On The Theory Of Vulnerability
}

\author{
WANG Xiang ${ }^{a}$, WANG Chuntao ${ }^{b}$ and FANG Haidong ${ }^{c}$ \\ China Design Group Co., Ltd., Nanjing, 210014, China

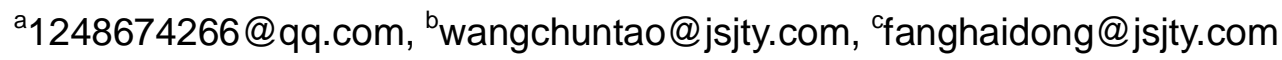

Keywords: bridge fire, vulnerability, safety design, risk assessment system, fuzzy comprehensive evaluation

\begin{abstract}
The mechanism model of bridge fire disaster is established by applying the theory of vulnerability. By using Delphi method analysis and screening the vulnerability factors, using cluster analysis and hierarchical analysis establish the evaluation index system of the vulnerability. The vulnerability assessment model is established by applying the method of Delphi and the Comprehensive Index method. Combining the mechanism model, influence factors, evaluation index system, evaluation model and safety countermeasures to build the bridge fire risk assessment system. Among them, the vulnerability evaluation index system can be used as a bridge safety design key control system. Research results can provide the theory basis for bridge risk assessment, safety design, operation and maintenance, etc, also provide the reference data for bridge design, maintenance and curing phase and upgrade stage.
\end{abstract}

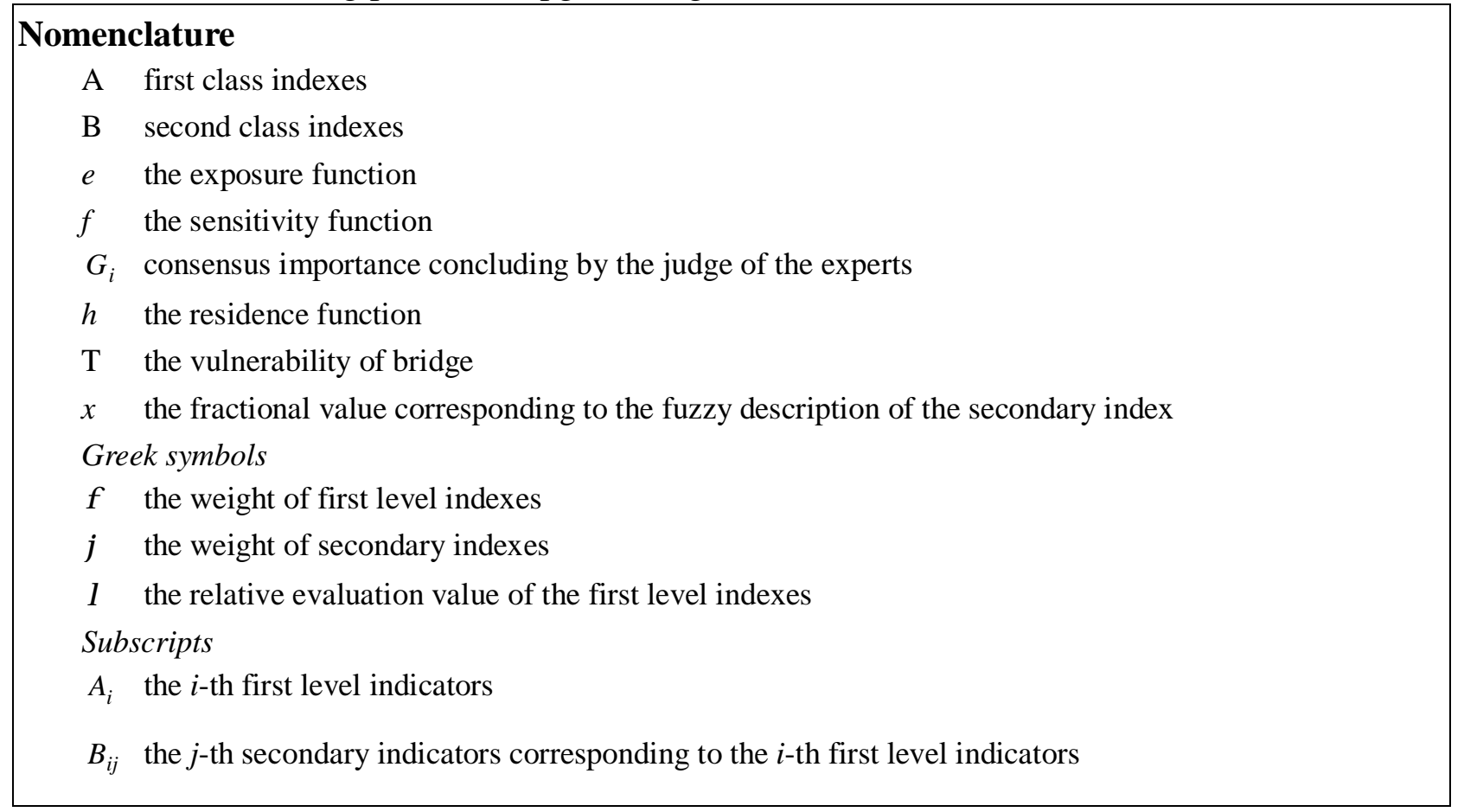

\section{Introduction}

In recent years, domestic and foreign bridge fire accidents happen frequently, which lead to casualties, traffic congestion, damage to the bridge structure, and cause great social impact and economic losses. Due to the rareness and complexity of bridge fire accidents, the development of bridge fire accident mechanism, risk warning and rescue strategy is slow and little relative research has been done. At home and abroad, fire protection design has not been considered in most of the bridge structures design. And the technical improvement in bridge fire prevention is not involved in 
the improvement of disaster prevention and mitigation of bridge engineering[1]. Zhang, G.[2] have studied the fire resistance performance of reinforced concrete beam bridge through the establishment of fire high temperature safety evaluation model. Hu, J.[3] studied the fire separation technology in building fire protection, which can be applied to fire protection of bridge structure. Sun B.[4] initially established a bridge fire risk assessment system which can guide the bridge fire accident mechanism and risk control system research. Garlock[5] studied the possible hazards of bridge fire, and Kodur[6] studied the key control factors for bridge fire safety design, which can be used to guide the bridge fire safety design research.

Vulnerability theory is an important complement to the theory of risk, which explains the nature of the disaster and has been applied in many fields. Yue, Y. L.[7] exploited the theory of vulnerability to study the impact of traditional threats on social and public safety. Giuliani L[8] studied the bridge fire vulnerability for the first time. Through the study of the vulnerability of bridge fire disaster, it can realize the exploration of the essence of bridge fire risk from the perspective of the bridge itself, which is of great significance to risk control, safety design and safety economic decision[9]. However, and the key of further reducing vulnerability is the vulnerability analysis and assessment of the bridge in design or operation phase[10].

\section{Analysis of Bridge Fire Disaster}

The causes of different fire scenarios are different, and their accident probability, influence consequence, safety prevention and control measures and on-site emergency response are also different.

The relationship between vulnerability and disaster is shown in equation (1-1):

$$
\text { Disaster Factor } \oplus \text { Vulnerability of Disaster Bearing Factor }=\text { Disaster Risk }
$$

The three elements of bridge fire disaster vulnerability are shown in Fig.1.

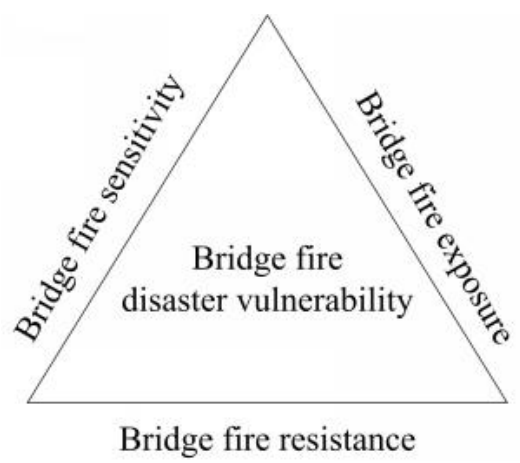

Fig.1 Three elements of bridge fire disaster vulnerability

\section{Vulnerability Assessment of Bridge Fire Disaster}

\section{Constructing the Mechanism Model of Bridge Fire Fragility Vulnerability}

The mechanism model of bridge fire disaster vulnerability is shown in Fig. 2. 


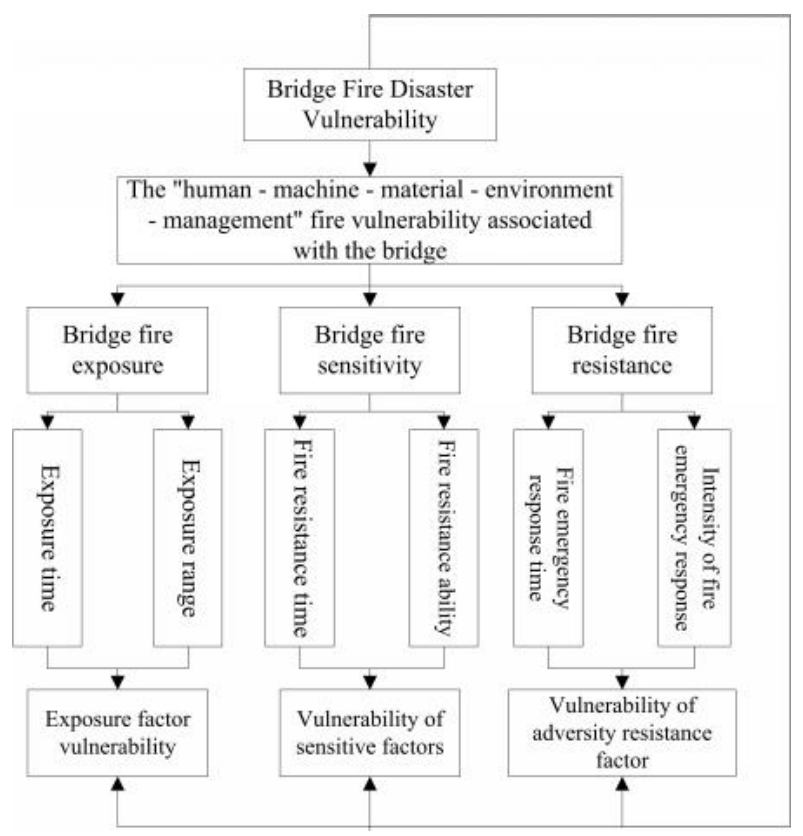

Fig. 2 The mechanism model of bridge fire disaster vulnerability

The vulnerability system of bridge fire disaster was constructed by cluster analysis and analytic hierarchy process, as shown in Fig. 3.

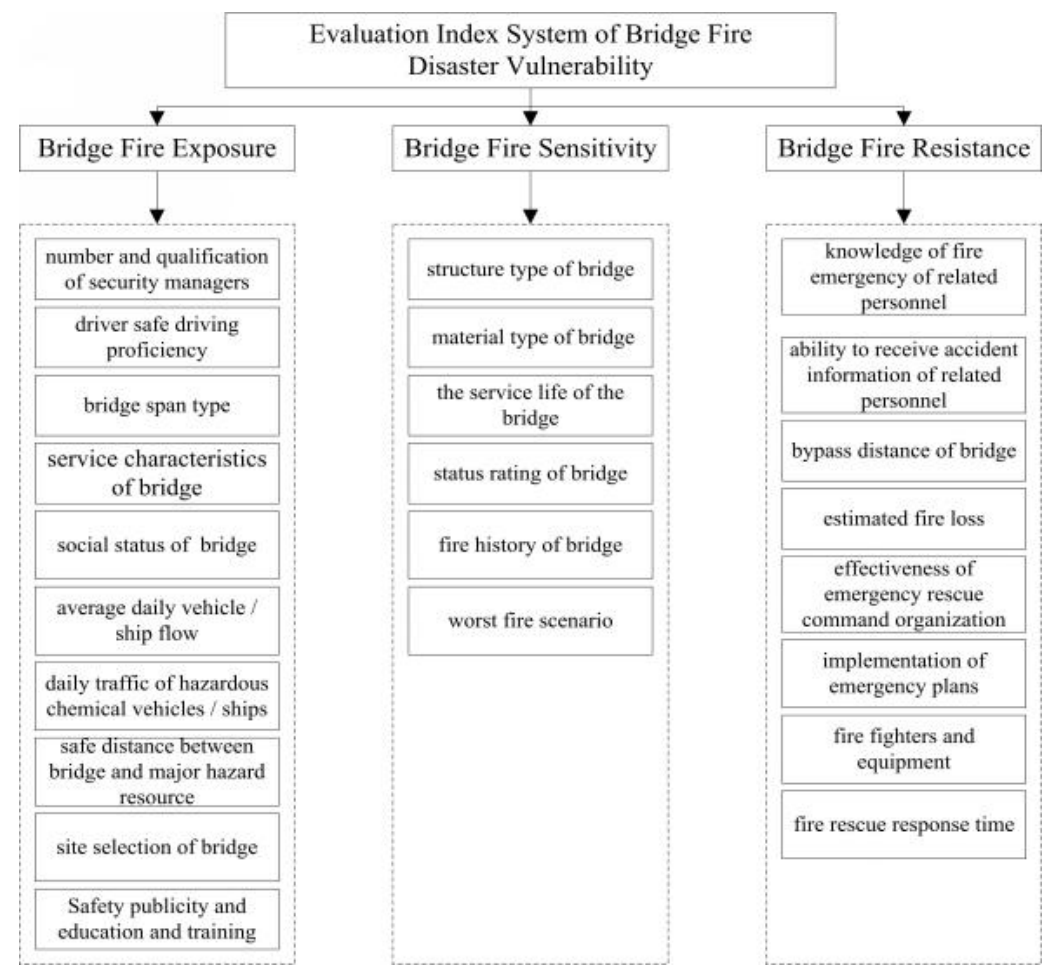

Fig. 3 Risk Assessment Index System of Bridge Fire

The secondary assessment indexes are quantified according to the "one-point system", such as dividing the score into 1 point, 2 point, 3 point, 4 point, 5 point from low to high, corresponding to the five levels respectively, namely, "one, two, three, four, five", the score is the relative weight of its indicators (the interaction between the indicators and Indicators are not considered). And the higher the level, the greater the weight of the index. The specific score and fuzzy description are shown in Table 1 and Table 2. 
Table 1. The grade standard of bridge fire disaster vulnerability secondary indexes

\begin{tabular}{|c|c|c|c|c|c|c|}
\hline \multirow{2}{*}{\multicolumn{2}{|c|}{$\begin{array}{l}\text { Evaluation Indexes } \\
\text { Secondary indexes } \\
\end{array}$}} & \multicolumn{5}{|c|}{$\begin{array}{l}\text { Classification and Value of } \\
\text { secondary indicators }\end{array}$} \\
\hline & & First & $\begin{array}{c}\text { Seco } \\
\text { nd }\end{array}$ & $\begin{array}{c}\text { Thir } \\
\text { d }\end{array}$ & $\begin{array}{c}\text { Four } \\
\text { th }\end{array}$ & Fifth \\
\hline \multirow{9}{*}{$\begin{array}{l}\text { Bridge Fire } \\
\text { Exposure } \\
\text { (A1) }\end{array}$} & $\begin{array}{l}\text { number and qualification of security managers } \\
\text { (B10) }\end{array}$ & 1 & 1.5 & 2 & 2.5 & 3 \\
\hline & driver safe driving proficiency (B11) & 1 & 2 & 3 & 4 & 5 \\
\hline & bridge span type (B12) & 1 & 2 & 3 & 4 & 5 \\
\hline & service characteristics of bridge (B13) & 1 & 2 & 3 & 4 & 5 \\
\hline & social status of bridge (B14) & 1 & 1.5 & 2 & 2.5 & 3 \\
\hline & average daily vehicle / ship flow (B15) & 1 & 2 & 3 & 4 & 5 \\
\hline & $\begin{array}{l}\text { daily traffic of hazardous chemical vehicles / ships } \\
\text { (B16) }\end{array}$ & 1 & 2 & 3 & 4 & 5 \\
\hline & $\begin{array}{l}\text { safe distance between bridge and major hazard } \\
\text { resource (B17) }\end{array}$ & 1 & 1.5 & 2 & 2.5 & 3 \\
\hline & site selection of bridge (B18) & 1 & 1.5 & 2 & 2.5 & 3 \\
\hline \multirow{7}{*}{$\begin{array}{l}\text { Bridge Fire } \\
\text { Sensitivity } \\
\text { (A2) }\end{array}$} & safety publicity and education and training (B19) & 1 & 2 & 3 & 4 & 5 \\
\hline & structure type of bridge (B20) & 1 & 2 & 3 & 4 & 5 \\
\hline & material type of bridge (B21) & 1 & 2 & 3 & 4 & 5 \\
\hline & the service life of the bridge (B22) & 1 & 1.75 & 2.5 & 3.25 & 4 \\
\hline & status rating of bridge (B23) & 1 & 2 & 3 & 4 & 5 \\
\hline & fire history of bridge (B24) & 1 & 1.5 & 2 & 2.5 & 3 \\
\hline & worst fire scenario (B25) & 1 & 2 & 3 & 4 & 5 \\
\hline \multirow{8}{*}{$\begin{array}{l}\text { Bridge Fire } \\
\text { Resistance } \\
\text { (A3) }\end{array}$} & $\begin{array}{l}\text { knowledge of fire emergency of related personnel } \\
\text { (B30) }\end{array}$ & 1 & 1.5 & 2 & 2.5 & 3 \\
\hline & $\begin{array}{l}\text { ability to receive accident information of related } \\
\text { personnel (B31) }\end{array}$ & 1 & 2 & 3 & 4 & 5 \\
\hline & bypass distance of bridge (B32) & 1 & 1.5 & 2 & 2.5 & 3 \\
\hline & estimated fire loss (B33) & 1 & 1.75 & 2.5 & 3.25 & 4 \\
\hline & $\begin{array}{c}\text { effectiveness of emergency rescue command } \\
\text { organization (B34) }\end{array}$ & 1 & 1.5 & 2 & 2.5 & 3 \\
\hline & implementation of emergency plans (B35) & 1 & 1.5 & 2 & 2.5 & 3 \\
\hline & fire fighters and equipment (B36) & 1 & 1.5 & 2 & 2.5 & 3 \\
\hline & fire rescue response time (B37) & 1 & 2 & 3 & 4 & 5 \\
\hline
\end{tabular}

Table 2. Fuzzy description of the vulnerability assessment index of bridge fire disaster

\begin{tabular}{|c|c|c|c|c|c|c|}
\hline \multirow{2}{*}{$\begin{array}{r}\quad E \\
\text { First } \\
\text { level } \\
\text { indexes } \\
\end{array}$} & \multirow{2}{*}{$\begin{array}{l}\text { Evaluation Indexes } \\
\text { Second level indexes }\end{array}$} & \multicolumn{5}{|c|}{$\begin{array}{c}\text { Three level index-The fuzzy description corresponding } \\
\text { to the quantitative grade of two level index }\end{array}$} \\
\hline & & 1 & 2 & 3 & 4 & 5 \\
\hline \multirow{3}{*}{$\begin{array}{l}\text { Bridge } \\
\text { fire } \\
\text { Exposur } \\
\text { e } \\
\text { (A1) }\end{array}$} & $\begin{array}{l}\text { number and qualification } \\
\text { of security managers } \\
\text { (B10) }\end{array}$ & $\begin{array}{l}\text { meet the } \\
\text { requirement } \\
\text { s }\end{array}$ & $\begin{array}{c}\text { lack of } \\
\text { personnel } \\
\text { and } \\
\text { qualification } \\
\mathrm{s}\end{array}$ & $\begin{array}{c}\text { not } \\
\text { configured }\end{array}$ & $\ldots$ & - \\
\hline & $\begin{array}{l}\text { driver safe driving } \\
\text { proficiency (B11) }\end{array}$ & $\square 10$ years & $5 \sim 10$ years & 3 5years & 2 3years & $<2$ years \\
\hline & bridge span type (B12) & $\leq 30 \mathrm{~m}$ & $30 \sim 100 \mathrm{~m}$ & $100 \sim 500 \mathrm{~m}$ & $500 \sim 1000 \mathrm{~m}$ & $\square 1000 \mathrm{~m}$ \\
\hline
\end{tabular}




\begin{tabular}{|c|c|c|c|c|c|c|}
\hline & $\begin{array}{c}\text { service characteristics of } \\
\text { bridge (B13) }\end{array}$ & $\begin{array}{l}\text { tractor } \\
\text { bridge }\end{array}$ & $\begin{array}{l}\text { pedestrian } \\
\text { bridge }\end{array}$ & $\begin{array}{l}\text { railway } \\
\text { bridge }\end{array}$ & $\begin{array}{l}\text { highway } \\
\text { bridge }\end{array}$ & $\begin{array}{l}\text { highway/ } \\
\text { railway bri } \\
\text { dge }\end{array}$ \\
\hline & $\begin{array}{r}\text { social status of bridge } \\
\text { (B14) }\end{array}$ & $\begin{array}{l}\text { regular } \\
\text { bridge }\end{array}$ & $\begin{array}{l}\text { landmark } \\
\text { bridge }\end{array}$ & $\begin{array}{l}\text { famous } \\
\text { bridge }\end{array}$ & & \\
\hline & $\begin{array}{l}\text { average daily vehicle / } \\
\text { ship flow (B15) }\end{array}$ & $<1000 / 100$ & $\begin{array}{l}1000 / 100 \sim \\
5000 / 500\end{array}$ & $\begin{array}{l}5000 / 500 \sim \\
20000 / 1000\end{array}$ & $\begin{array}{c}20000 / 1000 \\
\sim \\
50000 / 5000\end{array}$ & $\begin{array}{c}\square 50000 / 5 \\
0\end{array}$ \\
\hline & $\begin{array}{l}\text { daily traffic of hazardous } \\
\text { chemical vehicles / ships } \\
\text { (B16) }\end{array}$ & $<100 / 10$ & $\begin{array}{c}100 / 10 \sim 500 / \\
50\end{array}$ & $\begin{array}{c}500 / 50 \sim \\
1000 / 100\end{array}$ & $\begin{array}{l}1000 / 100 \sim \\
5000 / 500\end{array}$ & $\begin{array}{c}\square 5000 / 50 \\
0\end{array}$ \\
\hline & $\begin{array}{l}\text { safe distance between } \\
\text { bridge and major hazard } \\
\text { resource (B17) }\end{array}$ & $\begin{array}{l}\text { no major } \\
\text { hazardous } \\
\text { resource }\end{array}$ & $\begin{array}{c}\text { meet } \\
\text { spacing } \\
\text { requirement } \\
\mathrm{s}\end{array}$ & $\begin{array}{l}\text { insufficient } \\
\text { spacing } \\
\text { requirement } \\
\mathrm{s}\end{array}$ & & \\
\hline & $\begin{array}{l}\text { site selection of bridge } \\
\text { (B18) }\end{array}$ & $\begin{array}{l}\text { mountainou } \\
\text { s /rural area }\end{array}$ & suburbs area & urban area & & - \\
\hline & $\begin{array}{l}\text { safety publicity and } \\
\text { education and training } \\
\text { (B19) }\end{array}$ & $\begin{array}{c}\text { complete } \\
\text { safety } \\
\text { publicity } \\
\text { and } \\
\text { education } \\
\text { and training } \\
\text { materials, } \\
\text { many times }\end{array}$ & $\begin{array}{l}\text { complete } \\
\text { safety } \\
\text { publicity } \\
\text { and } \\
\text { education } \\
\text { and training } \\
\text { materials, } \\
\text { enough } \\
\text { times }\end{array}$ & $\begin{array}{l}\text { complete } \\
\text { safety } \\
\text { publicity } \\
\text { and } \\
\text { education } \\
\text { and training } \\
\text { materials, } \\
\text { regular } \\
\text { times }\end{array}$ & $\begin{array}{l}\text { complete } \\
\text { safety } \\
\text { publicity } \\
\text { and } \\
\text { education } \\
\text { and training } \\
\text { materials, } \\
\text { less times }\end{array}$ & $\begin{array}{l}\text { no related } \\
\text { materials }\end{array}$ \\
\hline & $\begin{array}{l}\text { structure type of bridge } \\
\text { (B20) }\end{array}$ & arch bridge & beam bridge & $\begin{array}{l}\text { rigid frame } \\
\text { bridge }\end{array}$ & $\begin{array}{l}\text { cable - } \\
\text { stayed } \\
\text { bridge }\end{array}$ & $\begin{array}{l}\text { suspension } \\
\text { bridge }\end{array}$ \\
\hline & $\begin{array}{l}\text { material type of bridge } \\
\text { (B21) }\end{array}$ & $\begin{array}{l}\text { masonry } \\
\text { bridge }\end{array}$ & $\begin{array}{l}\text { reinforced } \\
\text { concrete } \\
\text { bridge }\end{array}$ & $\begin{array}{l}\text { prestressed } \\
\text { reinforced } \\
\text { concrete } \\
\text { bridge }\end{array}$ & $\begin{array}{l}\text { steel-concre } \\
\text { te } \\
\text { composite } \\
\text { bridge }\end{array}$ & $\begin{array}{c}\text { steel } \\
\text { bridge / } \\
\text { wooden } \\
\text { bridge }\end{array}$ \\
\hline & $\begin{array}{c}\text { the service life of the } \\
\text { bridge (B22) }\end{array}$ & $<15$ years & 15 30years & 30 50years & $\square 50$ years & - \\
\hline $\begin{array}{l}\text { Bridge } \\
\text { fire }\end{array}$ & $\begin{array}{l}\text { status rating of bridge } \\
\text { (B23) }\end{array}$ & Category 1 & Category 2 & Category 3 & Category 4 & Category 5 \\
\hline $\begin{array}{l}\text { Sensitiv } \\
\text { ity }\end{array}$ & fire history of bridge (B24) & $\begin{array}{l}\text { High fire } \\
\text { perception }\end{array}$ & $\begin{array}{c}\text { Medium fire } \\
\text { perception }\end{array}$ & $\begin{array}{l}\text { Low fire } \\
\text { perception }\end{array}$ & $\begin{array}{l}\text { No fire } \\
\text { history }\end{array}$ & \\
\hline & worst fire scenario (B25) & $\begin{array}{c}\text { electric fire } \\
\text { near near } \\
\text { the bridge } \\
\text { fire } \\
\text { sensitive } \\
\text { structure } \\
\text { /arson/lighti } \\
\text { ng }\end{array}$ & $\begin{array}{c}\text { common } \\
\text { vehicle fires } \\
\text { near the } \\
\text { bridge fire } \\
\text { sensitive } \\
\text { structure }\end{array}$ & $\begin{array}{c}\text { major } \\
\text { hazard fire } \\
\text { near the } \\
\text { bridge }\end{array}$ & $\begin{array}{l}\text { dangerous } \\
\text { goods } \\
\text { vehicles / } \\
\text { ship fire } \\
\text { near } \\
\text { sensitive } \\
\text { structures }\end{array}$ & $\begin{array}{c}\text { hitting by } \\
\text { dangerous } \\
\text { goods } \\
\text { transport } \\
\text { vehicles / } \\
\text { ships }\end{array}$ \\
\hline & $\begin{array}{l}\text { knowledge of fire } \\
\text { emergency of related } \\
\text { personnel (B30) }\end{array}$ & $\begin{array}{l}\text { no fire } \\
\text { safety } \\
\text { training }\end{array}$ & $\begin{array}{l}\text { insufficient } \\
\text { fire safety } \\
\text { training }\end{array}$ & $\begin{array}{l}\text { regular fire } \\
\text { safety } \\
\text { training }\end{array}$ & 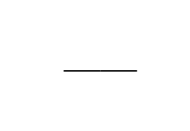 & \\
\hline $\begin{array}{l}\text { Bridge } \\
\text { fire } \\
\text { Resistan } \\
\text { ce }\end{array}$ & $\begin{array}{l}\text { ability to receive accident } \\
\text { information of related } \\
\text { personnel (B31) }\end{array}$ & $\begin{array}{c}1 \\
\text { emergency } \\
\text { access } \\
\text { channel }\end{array}$ & $\begin{array}{c}2 \text { emergency } \\
\text { access } \\
\text { channels }\end{array}$ & $\begin{array}{c}3 \\
\text { emergency } \\
\text { access } \\
\text { channels }\end{array}$ & $\begin{array}{c}4 \\
\text { emergency } \\
\text { access } \\
\text { channels }\end{array}$ & $\begin{array}{c}5 \square \text { emerge } \\
\text { ncy access } \\
\text { channels }\end{array}$ \\
\hline & $\begin{array}{l}\text { bypass distance of bridge } \\
\text { (B32) }\end{array}$ & $\square 30 \mathrm{~km}$ & $15 \sim 30 \mathrm{~km}$ & $<15 \mathrm{~km}$ & - & \\
\hline
\end{tabular}




\begin{tabular}{ccccc}
\hline estimated fire loss (B33) & $\begin{array}{c}\text { extraordinar } \\
\text { ily serious } \\
\text { accident }\end{array}$ & $\begin{array}{c}\text { major } \\
\text { accident }\end{array}$ & big accident & $\begin{array}{c}\text { general } \\
\text { accident }\end{array}$
\end{tabular}$-$

\section{Vulnerability assessment model based on Delphi Method-Composite Index Evaluation Method}

Assumption: (1) Exposure, sensitivity and stress resistance are independent of each other, contributing to the vulnerability of equality; (2) The higher the exposure and sensitivity in a particular system (such as bridges) in a particular disturbance (such as fire) while the lower the ability of the system to respond to disturbances, the higher the vulnerability of the system; (3) The vulnerability is linearly related to the degree of exposure, sensitivity and resistance; (4) Vulnerability is positively correlated with exposure and sensitivity, while negatively correlated with stress resistance.

Based on the hypothesis, the evaluation model of linear correlation function is established:

$$
\mathrm{T}=\frac{\mathrm{e} \cdot \mathrm{f}}{h}
$$

Delphi Method-Composite Index Evaluation Method is a combination of Delphi method and the composite index method used to improve the defects of expert judgment, reducing the differences, subjectivity and fuzziness in the expert scoring.

The specific calculation steps involved in the Delphi-Comprehensive Index Assessment are as follows:

Determine the weights of the secondary indicators.

$$
\varphi_{B i j}=x
$$

Calculate the weight of the first level indexes.

$$
\phi_{A \mathrm{i}}=\frac{\sum_{j=1}^{k} \max \left\{\varphi_{B i j}\right\}}{\varphi_{\text {max }, \text { total }}}
$$

Calculate the evaluation value of the secondary indexes.

$$
\varphi_{A i, B i j}=G i
$$

Calculate the evaluation value of the first level indexes. 


$$
\Delta_{A i}=\frac{\sum_{j=1}^{k} \varphi_{A i, B i j}}{\sum_{j=1}^{k} \max \left\{\varphi_{B i j}\right\}}
$$

Calculate the relative evaluation value of the first level index.

$$
\lambda_{i}=\Delta_{A i} \cdot \phi_{A i}
$$

Repeat step 1 step 5 and calculate the relative evaluation value of all the first level index, $\lambda_{1}, \lambda_{2}, \lambda_{3}$.

Taking the value of $\lambda_{1}, \lambda_{2}$ and $\lambda_{3}$ as the judgment standard, determine the grade of the exposure, sensitivity and resistance of the evaluation object according to the 5 intervals obtaining by dividing the index evaluation range into 6 pieces equally.

Calculate the vulnerability score of assessment object.

Substitute $\lambda_{1}, \lambda_{2}$ and $\lambda_{3}$ into formula (3-1):

$$
T_{0}=\frac{\lambda_{1} \cdot \lambda_{2}}{\lambda_{3}}
$$

According to the $5 \%$ (excellent), $15 \%$ (good), 60\% (middle) of the maximum value of the vulnerability assessment which is divided into four grades, and then determine the vulnerability level according to the assessment score.

\section{Conclusion}

To reduce the vulnerability of bridge fire disaster, following can be considered:

( 1 ) Fire protection design for fire vulnerable / sensitive components.

Fire facilities, equipment and fire sensitive structures should be equipped with fire extinguishers, emergency rescue telephone and emergency communication broadcast on the bridge. And fire sensitive structure can be painted with thick fireproof coating.

( 2 ) Sensitive structures are equipped with anti-collision facilities.

The navigation mark is supposed to be set under the bridge, and the crash pads are built on the piers, and the anti-collision barrier is arranged on both sides of the bridge.

( 3 ) Manage of the transportation vehicle/ship of dangerous goods.

The classification and monitoring of transport vehicles and ships shall be carried out according to the fire source power of dangerous chemicals. The monitoring of bridge decks and under-bridge shall be strengthened when the vehicles and vessels with high dangerous level passing.

( 4 ) Fire safety management / education training system.

Operating units are responsible for the identification and control of fire hazard, regular safety inspection, external experts for safety training and training professional team.

Conduct emergency plan drills regularly.

Improve emergency response plan, regular safety drills. 


\section{Reference}

[1] Ma, J., Sun, S.Z., Yang, Q., 2014. Review on China ' s Bridge Engineering Research, China Journal of Highway and Transport 27, p. 1.

[2] Zhang, G., He, S.H., Song, Y.F., 2008. Safety evaluation for reinforcement concrete girders exposed to fire, Journal of safety and environment 8, p. 153.

[3] Hu, J., 2016. Discussion on application of Fire Separation Technology in building fire, Public security in China (academic edition) 3, p. 44.

[4] Sun, B., Xiao, R.C., 2015. Bridge fire risk assessment system based on Analytic Hierarchy Process-Fuzzy Comprehensive Evaluation method, Journal of Tongji University (natural science edition) 43, p. 1619.

[5] Garlock M E M., 2010. Review And Assessment Of Fire Hazard In Bridges, Transportation Research Record Journal of the Transportation Research Board 13, p. 23.

[6] Kodur V K R, Naser M Z., 2013. Importance factor for design of bridges against fire hazard, Engineering Structures 54, p. 207.

[7] Yue, Y.L., 2012. Non traditional security threats and social public security, Public security in China (academic edition) 4, p.16.

[8] Giuliani L, Crosti C, Gentili F., 2012. Vulnerability of bridges to fire, Rammed Earth Conservation, p. 313.

[9] Fan, Y.X., Luo, Y., Chen, Q.S., 2000. Discussion on quantification method of evaluating vulnerability indexes of hazard bearing body, Journal of Catastrophology15, p. 18.

[10] Wang, X., Tao, G., Zhang, L. J., 2015. Risk analysis of damage of bridge steel tower caused by vehicle burning based on fuzzy group decision-making, Fire Science and Technology 34, p.644. 